\title{
The Effectiveness of Using the Youtube Platform in Learning Videos Making Posters for Elementary School Students during the Covid-19 Pandemic
}

\author{
Suniandra Jarizmy ${ }^{1}$, Rina Maryanti2,*, Verra Wulandary ${ }^{3}$, Asep Rudi Irawan ${ }^{4}$ \\ ${ }^{1}$ Departemen Pendidikan Sejarah, Universitas Pendidikan Indonesia. \\ ${ }^{2}$ Departemen Pendidikan Kesejahteraan Keluarga, Universitas Pendidikan Indonesia. \\ ${ }^{3}$ Graduate School of International Development and Cooperation, Hiroshima University, \\ Japan. \\ ${ }^{4}$ School of Human Sciences, University of Tsukuba, Japan \\ *Corresponding Author : maryanti.rina@upi.edu
}

\begin{abstract}
Abstrak: Penyebaran virus Covid-19 di Indonesia masih terjadi. Hal tersebut menyebabkan semua sekolah yang berada di Indonesia memberlakukan pembelajaran jarak jauh. Bermacam platform memudahkan para guru untuk melakukan pembelajaran jarak jauh terhadap para siswa, salah satunya adalah platform Youtube. Tujuan dari pengabdian kepada masyarakat ini untuk mengetahui efektivitas penggunaan platform Youtube dalam melakukan pembelajaran melalui video. Metode dalam pengabdian kepada masyarakat ini menggunakan pendekatan deskriptif kualitatif yang dilakukan melalui observasi lapangan dan wawancara. Berdasarkan hasil kegiatan tersebut, penggunaan platform Youtube dapat dikatakan efektif dalam memberikan video pembelajaran membuat poster pada siswa sekolah dasar serta platform Youtube bisa diakses secara gratis oleh setiap siswa di masa pandemik ini. Pembelajaran melalui video membuat peserta didik menjadi semangat dan antusias saat menjalani proses pembelajaran tersebut.
\end{abstract}

Kata kunci: Covid-19, efektivitas, platform Youtube, sekolah dasar, video pembelajaran.

\begin{abstract}
The spread of the Covid-19 virus in Indonesia is still happening. This causes all schools in Indonesia to apply distance learning. Various platforms make it easy for teachers to conduct distance learning for students, one of which is the Youtube platform. The purpose of this community service is to find out the effectiveness of using the Youtube platform in conducting learning through video. This method of community service uses a qualitative descriptive approach which is carried out through field observations and interviews. Based on the results of these activities, the use of the Youtube platform can be said to be effective in providing learning videos to make posters to elementary school students and the Youtube platform can be accessed for free by every student during this pandemic. Learning through videos makes students enthusiastic and enthusiastic while undergoing the learning process.
\end{abstract}

Keywords: Covid-19, effectiveness, elementary school, learning videos, Youtube platform. 


\section{Introduction}

The Covid-19 pandemic has caused many countries to decide to close all educational institutions. According to data from the Organization for Education, Science, and Culture of the United Nations (UNESCO), there are 290.5 million students worldwide who experience disruption in teaching and learning activities due to school closures due to the pandemic Covid19 that happened suddenly. According to Jonsson, students who attend the school will increase their memory capacity (Jonsson et al., 2017). Activity restrictions are one of the policies of the government that must be followed by Indonesian citizens. One of the sectors experiencing restrictions on activities in carrying out activity is the education sector. The impact of this Coronavirus Disease (Covid-19) occurs in all walks of life, from preschool to university some policy changes as the minister of education and Indonesian culture in Circular No. 3 and Circular No. 4 of 2020. Emergency period the spread of Covid-19 automatically education units and policy implementation education must use the two policies of the Minister of Education and Culture as a reference. Distance learning (online) or commonly known as learning at home is a policy issued by the Minister of Education and Culture (SE Mendikbud, 2020). The impact of the Covid-19 pandemic on education includes, students experiencing compulsion in learning without adequate facilities and infrastructure at home, students have never done remote learning activities, schools are closed too long so that it makes students bored at home, there are additional costs in purchasing internet quota, teachers to adapt to technology and ownership of adequate facilities and infrastructure (Purwanto et al., 2020). The impact of the Covid-19 pandemic on education includes students experiencing compulsion in learning without adequate facilities and infrastructure at home, students have never done remote learning activities, schools are closed too long so that it makes students bored at home, there are additional costs in purchasing internet quota, teachers to adapt to technology and ownership of adequate facilities and infrastructure (Purwanto et al., 2020).

Youtube was first launched in 2005 and since then the level of popularity has increasingly peaked as a video-sharing website (Holland, 2016). In education, Youtube can be used to illustrate subject content, engage students in finding information for a project, as well as inspire innovative teaching methods (Agazio \& Buckley, 2009). With the Youtube platform, students can easily access learning videos made by teachers so that learning becomes interesting because they use audio visuals in the learning process.

Basically, video is a tool or media that can show real objects. Video as a digital medium 
that can show the form of an arrangement or sequence of coherent images and provide illusions, images and fantasies to moving images. Video provides a very interesting way of conveying information. Video is the most dynamic and effective source or media in conveying information (Limbong \& Simarmata, 2020).

Based on the explanation above, the purpose of the research conducted by us is to determine the effectiveness of using the Youtube platform as a learning medium to assist teachers in the learning process to make posters on the subject of Cultural Arts for Elementary School Students by reviewing previous research articles with relevant titles and conduct field research on Elementary School Students. We believe that the learning videos are made as interesting as possible so that students are interested in listening to the lessons.

Poster is one of the media to convey information which consists of symbols or very simple words. In general, posters contain recommendations or prohibitions on certain information. Posters are a visual combination of images, lines, and colors. Posters can be effective in learning situations, generate interest in learning, encourage social skills, motivate and encourage students to read more (Smaldino et al., 2012). Posters can build knowledge and enhance communication skills (Kelsch and Werremeyer, 2011). Posters can also have an influence on social trust in sharing information. The formation of social cognitive structures can be influenced by peers so that they make a positive contribution to the attitudes and knowledge intentions of students through pictures (Liao and Chou, 2012).

The beginning of the Youtube platform was founded by Chad Hurley, Steve Chen, and Jawed Karim who were previously PayPal's first employees. At first, Youtube was created only for entertainment. But along with the times and technology has developed drastically, Youtube is widely used for various things, one of which is as a learning medium. Youtube is a social media platform that contains online videos or on Youtube there are various kinds of videos stored in online storage in the form of the Youtube platform, so that videos can be viewed and accessed by anyone and anywhere as long as there is access. internet (Tutiasri et al., 2020). Youtube is very easy to access by anyone, so many teachers use the Youtube platform as a learning medium. In addition, Youtube has many functions with an increasingly attractive appearance as time goes on.

\section{Methods}

This activity was conducted at SD Yakeswa which is located on Jl. Dr. Hatta No. 54/29 
Jurnal Abdimas Kartika Wijayakusuma ISSN 2716-3512 (Online) ISSN 2721-0367 (Print)
This work is licensed under a Creative Commons Attribution-ShareAlike 4.0 International License.

B, Bandung City, West Java. This study uses a descriptive method with a qualitative approach. A qualitative descriptive method is a result method based on the philosophy of postpositivism used to examine the condition of a natural object (as opposed to an experiment) where the researcher is the key instrument. Qualitative results emphasize meaning rather than generalization (Sugiyono, 2016). This study aims to determine how effective the Youtube platform is in learning videos to make posters for elementary school students. This study was conducted by 10 students consisting of 5 male students and 5 female students. The survey was conducted by distributing Post-Tests to students and then uploading learning videos to make posters on the Youtube platform and giving time for students to watch the learning videos. After that, the students will be given a Pre-Test regarding the learning video with the same number and weight of questions. Comparison of Pre-Test and Post-Test results will be used in this study. The tool used to collect these results is in the form of an online form that has been provided to support the research.

\section{Result and Discussion}

This study was conducted using the technique of collecting data and field result. In this demographic, there are 10 students consisting of 5 male students and 5 female students. Students are given the initials I to $\mathrm{R}$ to facilitate the research process.

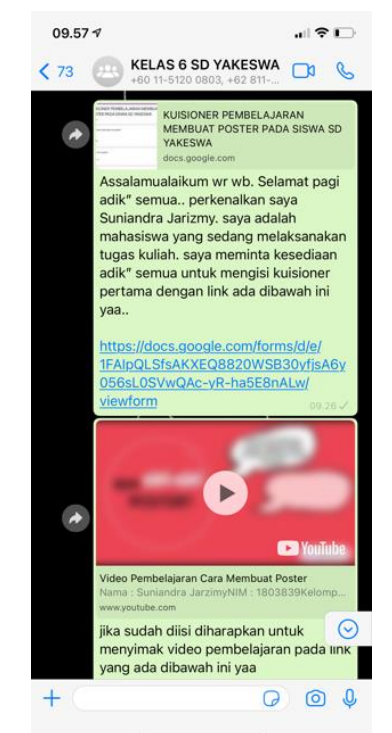

Figure 1. Distribution of questionnaires via WhatsApp 
Jurnal Abdimas Kartika Wijayakusuma ISSN 2716-3512 (Online) ISSN 2721-0367 (Print)
This work is licensed under a Creative Commons Attribution-ShareAlike 4.0 International License. CC BY SA

In Figure 1, the questionnaire is distributed to the class group of elementary school students. At this stage students are required to fill out a questionnaire that has been provided. After that, the students listen to the learning videos that have been uploaded on the Youtube platform as shown in Figure 2.

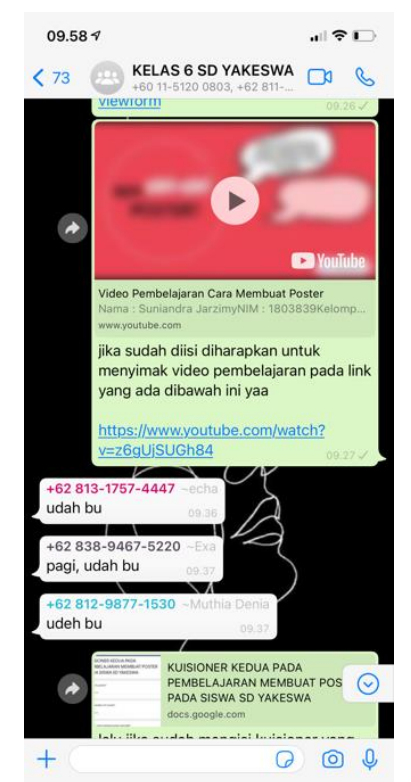

Figure 2. Distribution of learning video links on the Youtube platform via WhatsApp

After the students watched and listened to the learning video which was uploaded on the Youtube platform, the students were given a questionnaire again to fulfill this study with the same weight of questions as captured in Figure 3.

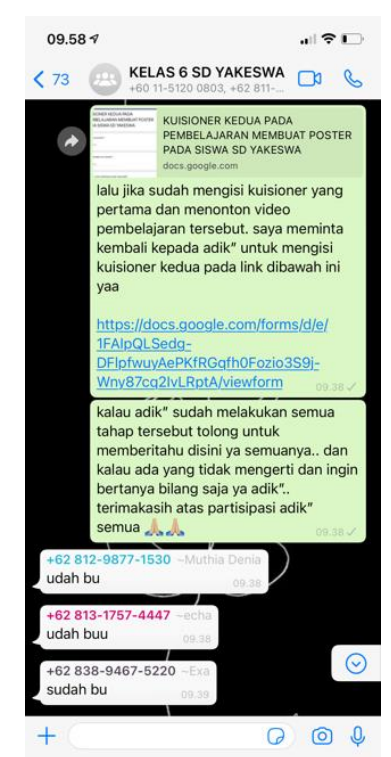

Figure 3. Distribution of questionnaires via WhatsApp

Volume 2, Nomor 2, Oktober 2021| 150

The Effectiveness of Using the Youtube Platform in Learning Videos Making Posters for Elementary School Students during the Covid-19 Pandemic 
Jurnal Abdimas Kartika Wijayakusuma ISSN 2716-3512 (Online) ISSN 2721-0367 (Print)
This work is licensed under a Creative Commons Attribution-ShareAlike 4.0 International License.

Meanwhile, the activity is divided into three stages that is Pre-Test, Treatment and PostTest. We gathered a total of 10 grade 6 elementary school students to assist with this result. There were 5 male students and 5 female students who were given the initials I to R. At the initial stage, we distributed a questionnaire containing 10 questions to students to find out whether these students had understood the learning material for making posters that had been explained in the previous lesson. It can be seen from Figure 4 that only students with the initials I, K, L, and R already understand the material that has been explained, while students J, M, N, $\mathrm{O}, \mathrm{P}$, and $\mathrm{Q}$ still do not understand the explanation of the material for making posters that have been described previously.

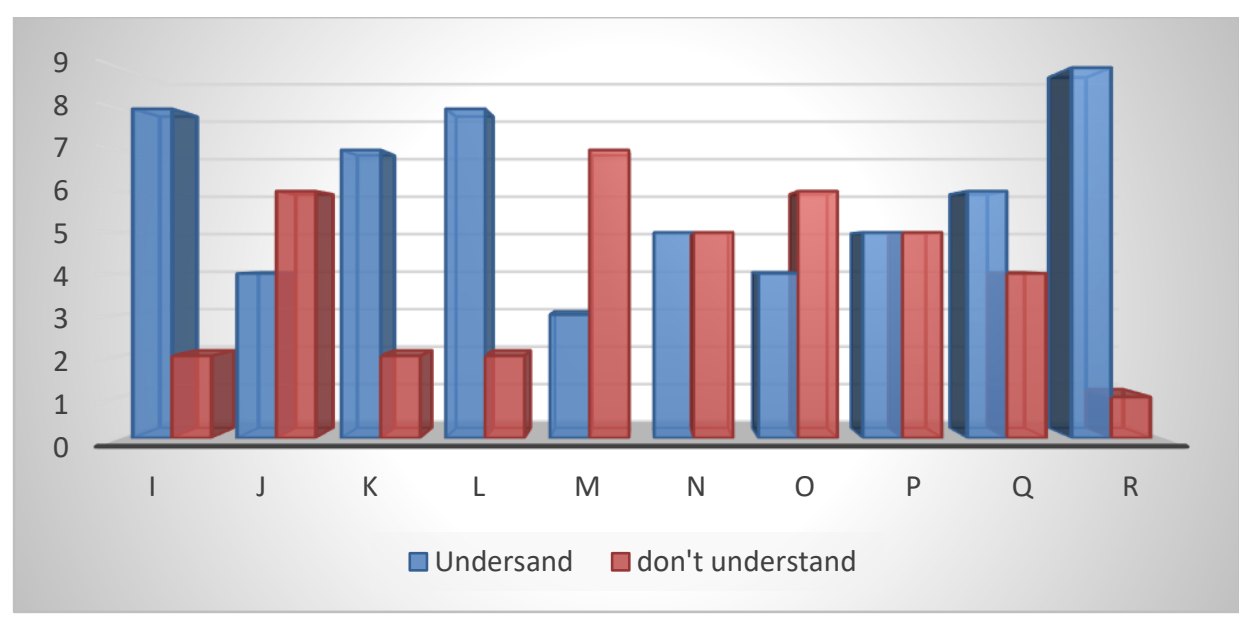

Figure 4. Pretest results.

In the second stage, namely the treatment stage, we spread the video upload link on the Youtube platform that has been provided for the students to listen and study. Then we gave time for the students to watch the learning video while preparing the Post-test questions for the third stage. We make learning videos as interesting as possible so that students can easily understand the learning.

In the third stage, we distributed the questionnaire with a balanced weight of questions with learning videos to make posters that have been uploaded with the Youtube application. 


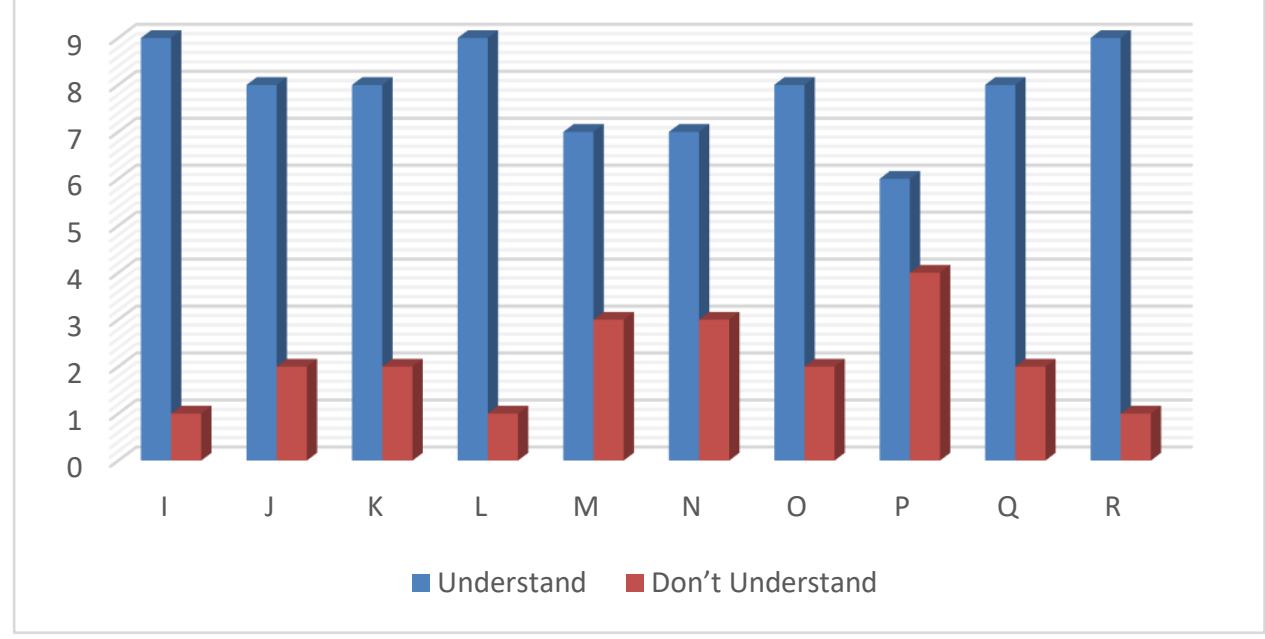

Figure 5. Post-Test results.

As observed from Figure 5, the results of the students' questionnaires look quite good from the previous results. After watching the learning videos that have been given to students via uploads on the Youtube platform, it causes students to be more enthusiastic in understanding and learning how to make the poster. It can be seen that students with the initials J, M, N, O, $\mathrm{P}, \mathrm{Q}$, and $\mathrm{Q}$ in answering the questions have more correct and different answers than the previous ones, while students I, K, L, and R, which also improved the number of correct questions in the Post-Test results. This proves that learning videos on the Youtube platform are more effective in increasing student interest. With this interest, the quality and value of each student increases. Although video learning is very effective in improving quality and value, students still have to be guided by their parents because the Youtube platform is very diverse.

\section{Conclusion}

The use of the Youtube platform is very useful to make it easier for teachers to access and provide learning videos to students during this pandemic, so that learning becomes fun and easy for students to understand. By uploading learning videos on the Youtube application, it indirectly increases student interest in learning during the Covid-19 pandemic. Because during this covid-19 pandemic, everyone has to fight to get and provide knowledge to many people so that they can still gain knowledge even though they are being hit by a disaster. With this Youtube platform, it is very easy for teachers and students to provide and also gain knowledge during the Covid-19 pandemic. However, students are still under the supervision of parents because the Youtube platform is very broad in scope and can be accessed by anyone easily. 


\section{Acknowledgment}

We acknowledged Bangdos, Universitas Pendidikan Indonesia. We thank to Linda Nursyahidah, S.Pd. from Yakeswa Elementary School. This study is a part of community service (Program: KKN Tematik Literasi 2021 (August-Sept 2021) kelompok 20) Lembaga Penelitian dan Pengabdian Masyarakat (LPPM), Universitas Pendidikan Indonesia. We also thank to Kantor Jurnal dan Publikasi, Directorate of International Affairs, Universitas Pendidikan Indonesia. We thank to Nissa Nur Azizah, Dwi Fitria Al Hussaeni, Rina Maryanti, S.Pd., M.Pd., Dr.Eng. Asep Bayu Dani Nandiyanto, S.T., M.Eng., Muktiarni, S.Pd., M.Pd., and Asri Wibawa Sakti, M.Pd.

\section{References}

Agazio, M. J. \& Buckley, M.K. 2009. An Untapped Resource: Using YouTube inNursing Education. Nurse Educator, 34(1), 23-28.

Holland, M. 2016. How YouTube Developed into a Successful Platform for User-Generated Content. Elon Journal of Undergraduate Research in Communications, 7(1), 52-59.

Jonsson, B., Waling, M., Olafsdottir, A.S., Lagström, H., Wergedahl, H., Olsson, C., Fossgard, E., Holthe, A., Talvia, S., Gunnarsdottir, I. \& Hörnell, A. 2017. The Effect of Schooling on Basic Cognition in Selected Nordic Countries. Eur J Psychol., 13(4), 645-666.

Kelsch, M.P. \& Werremeyer, A.B. 2011. Poster project to emphasize public health in the pharmacy curriculum. Am J Pharm Educ., 75(1), 2-11.

Liao, S. \& Chou, E. 2012. Intention to adopt knowledge through virtual communities: posters vs lurkers. Online Information Review, 36(3), 442-461.

Limbong, T. \& Simarmata, J. 2020. Menentukan Matakuliah yang Efektif Belajar Daring (Belajar dan Ujian) dengan Metode Multi-Attribute Utility Theory (MAUT). Jurnal Resti, 4(2), 370-376.

Purwanto, A., Asbari, M., Fahlevi, M., Mufid, A., Agistiawati, E., Cahyono, Y. \& Suryani, P. 2020. Impact of Work from Home (WFH) on Indonesian Teachers Performance During the Covid-19 Pandemic: An Exploratory Study. International Journal of Advanced Science and Technology, 29(5), 6235-6244.

Smaldino, S.E., Lowther, D.L. \& Russell, J.D. 2012. Instructional Technology and Media for Learning. Pearson Education Inc.

Sugiyono. 2016. Metode Penelitian Kuantitatif, Kualitatif dan R\&D. PT Alfabet. Bandung.

Tutiasri, R. P., Laminto, N. K. \& Nazri, K. 2020. Pemanfaatan Youtube Sebagai Media Pembelajaran Bagi Mahasiswa di Tengah Pandemi Covid-19. Jurnal Komunikasi Masyarakat Dan Keamanan (KOMASKAM), 2(2), 1-15. 